\title{
Job description form as an approach to work quality: specifying problems and strategic planning tool: the case study of Mercure hotel chain
}

\author{
Nabeel Aly Aly Ahmad Badran Hesham Ezzat Saad Gad \\ Faculty of tourism and hotels, Fayoum University
}

\begin{abstract}
One of the important reasons for delays and errors in an activity is not having clarity on the tasks to be achieved with clear authorities and responsibilities. In order to do the jobs effectively the tasks are to be specified for each one in the organization and without overlapping of authorities and responsibilities. Job description form plays an integral role to do that. An accurate form can play a strategic role in the workplace big activities; planning, organizing, controlling and training of people as well. The purpose of this study was to describe and analyze the role of job description form as a strategic tool sharing effectively in the planning process and to investigate how far job description form (JDF) can affect work of human resources and solve problems which may occur. The approach of the study was the case study of Mercure five-star hotels in Egypt. Eighty six structured questionnaires were done with entitled persons and executives in these hotels as a case study. Statistical and content analyses were used to primary data. Specific hypotheses were tested and different recommendations were presented.
\end{abstract}

\section{Keywords: Mercure chain, Human resources, strategic planning, training}

\section{Review of literature}

Human resources represent one of the most important investments of the company (George \& Zakkariya; 2015), so managers should match members to the goals, recognize the differences, use goals and ensure that they are attainable, individualize rewards and link them to performance. A job description analyzes, evaluates the jobs and prepares the pay scale properly to fit the job complexity and the hierarchical level and establish an appropriate salary grid and accurately assess compensation levels based on the complexity and liability of specific work responsibilities (Sîrbua \&Pinteaa, 2014; Massad, 2005).

Thus, the manager should establish accurate job descriptions for all team members. A job description is not a mere statement of what the employee has to do (Pató \& Sz; 2015) but also, it includes a philosophy statement, a list of needed skills, a list of other job duties and a list of activities, accountabilities and other data about how job performance should be evaluated (Heathfield, 2016).

Levin (2005) added that clearly job tasks will never have a higher level of conflict. A well transparent job description can help management to set perfect performance reviews which determine what has gone right in past months?, what does the employee need to improve during next months?, how can the organization perform better overall? And how can the manager do a better job?. Moreover, job descriptions (JDs) should clear competencies and qualifications needed for every job. In addition, JDs should be more determined rather than vague, written in behavioral terms, and use quantitative verbs to describe actions (Manning et al., 2012; Bart, 2012).

In essence, Peregrin (2014) argued that employing and selecting the wrong worker can have bad effects on the organization's morale and stress levels. In addition, ineffective hires can cost an employer $\$ 25,000$ according to findings published by the National Business Research Institute, while the US Department of Labor estimates the cost of a bad hire to be $30 \%$ of the employee's annual salary. So, competency based hiring not only improves recruitment efforts, according to industry experts but also, enhances the retention of knowledgeable employees and guides performance management (Scott, 2011), talent review, and professional development for staff throughout the organization. Also, JDs can be beneficial to having challenging and meaningful work force, more loyal to their profession than to the organization, less accommodating of traditional structures and authority, more concerned about work life balance.

Pradhanc (2014) emphasized that a proactive job description help to identify factors that form the employees' motivation and job satisfaction (Linz; 2003). Using such JDs enable the organization to possess far better knowledge of their strengths and limitations, and can take timely corrective action to improve any deficiencies in their skills and job behaviors. 
Moreover, Berkeley (2016) stated that job description isn't just a piece of paper that appears in an employee's file. It's a vital document that helps hire, manage, encourage, review, and, if necessary, discipline or terminate employees. By clearly stating what you expect of your employees, it provides a solid foundation for all of your management actions. It also dictates success or, conversely in its absence, allows a climate of conflict, shoddy work practices, vague and subjective performance evaluations, and organizational disharmony.

Lanier (2009) reported that a job description helps to prevent overlapping of duties and assigns task responsibility. This gives a job seeker an idea of what kind of person the position is intended for and helps the employer identify the best applicant for the position. It also provides information in the performance appraisal process and to judge whether the candidate is the right person for a promotion. Moreover, it also helps employees in deciding their career paths and to train themselves according to the education and skill required by their target position (Stetz et al., 2011; Gan \& Kleiner, 2005).

In addition, Pennell (2010) argued that JDs help organizations to identify management talent and capabilities, establishes a broad base of leadership ready to take on new challenges, and avoids the disruption that can result from ill-timed promotions and inadequately prepared managers and develop and retain talent for key positions that are in line with current business objectives (Butler; 2008). Flexible job descriptions allow for rotating assignments and cross-training.

Hsieh \& Hsieh (2003) stated that JDs can eliminate causes of job burnout which result dangerous outcomes (i.e. role ambiguity, role overload, role conflict). In addition, Sîrbua \&Pinteaa (2014) \&Massad (2005) added, typically, until the identification of detailed and accurate requirements for the holder of a work station, both in terms of tasks and required behavior, we cannot design a professional recruitment system, a training program and we cannot build a system of staff evaluation so without JDF so, the need for a sound job description system is extremely vital.

They also focused that JDs mainly used as administrative control tool (planning (Marr, 2013), defining role and organization of workforce), a strategic HR tool (Job evaluation, recruitment of staff, personnel selection, training of staff (Lee et al., 2014), professional appreciation, promotion, transfer and career development) and as a professional tool to specify design of jobs and equipment. Furthermore, the human resources department might take advantage of these JDs in order to identify competencies for each job and to develop an optimized policy of recruitment (Bednarek-Michalska; 2002).

Effective JDs can lead a successful behavioral interview so; an interviewer should be prepared to ask competency based questions. This enables the organization to set goals and objectives for annual reviews, identify areas for professional development and training (Pennell; 2010) and enhance employee engagement and retention of employees.

Chow \& Kleiner (2002) and Herrick (2009) dictated that the job description can develop objective jobrelated interview questions, formalize objective performance appraisals, conduct personnel functions in a non-discriminatory manner, Smooth wage and salary administration and simplify human resource management. On the other hand, Hill (1995) and Carliner et al. (2015) and Carliner, (2012) argued that organizations can use the job description to well form the advertisements of employment to be provided with suitable candidates.

Blickle et al. (2009) discussed that job performance ratings were assessed with five items assessing task performance, adaptive performance, and job dedication (Blickle et al., 2008; Schmitt et al., 2003) so, JDs are so vital to manage performance on a logic basis. Rohr (2016) and Kondrasuk et al. (2001) stated that any performance deficiencies, as identified during the performance evaluation or the hiring process, can be addressed with training. Because the performance evaluation and hiring process is based on the job description, identifying training needs is fairly straightforward. In addition, job descriptions can play a vital role in succession planning. Organizations utilizing information systems, can carefully create an inventory and track employees' knowledge, skills, abilities and behaviors.

Utilizing a job description can help with health and safety. The organization to make sure that employees are not performing jobs that they are not qualified to perform (Mondy \& Martocchio; 2014). 


\section{Importance of the study}

Ineffective hires can cost an employer $\$ 25,000$ or more, according to findings published by the US Department of Labor which also estimates the cost of a bad hire to be $30 \%$ of the employee's annual salary (Peregrin, 2014).

\section{Purpose of the study}

The purpose of this study was to describe and analyze the role of job description form as a strategic tool sharing effectively in the planning process and to investigate how far job description form (JDF) can affect work of human resources and solve problems which may occur.

\section{Objectives of study}

a) To present the perception of management towards the benefits and outcomes of JDF,

b) To spotlight on the importance of JDF in human resources functions, and

c) To declare to what extent the Mercure chain makes best use of JDF in strategic planning.

\section{Hypotheses of the study}

H1: management of Mercure chain realizes the importance of JDF.

$\mathrm{H} 2$ : there is a significant positive correlation between the extent of using JDF in planning and the extent of using JDF in recruitment \&selection of human resources in context to Mercure hotel chain.

H3: there is a significant positive correlation between the extent of using JDF in planning and the extent of using JDF in training of human resources in context to Mercure hotel chain.

\section{Methods of the study}

Descriptive research was performed. A face-to-face survey was carried out. The research involves managers and assistant managers of four hotels comprising the total number of the Mercure hotel chain (Mercure le sphinx, Mercure Hurghada, Mercure Luxor and Mercure Ismailia). A questionnaire was used. Questions were rated on a 5-point scale (strongly disagree to strongly agree). A total of 86 successful responses were achieved. A purposive sampling was adopted to select the target respondents for the questionnaire survey. The study also did a content analysis to a number of JDFs related to the kitchen of Mercure and a matrix was done in relation to the training plan of 2016 within the chain. The aim of the matrix was to spotlight the relationship between JDF and the training plan as a clue of good practice.

The Cronbach's alphas of the importance, planning and human resources functions in this study were .91, .95 , and .94 respectively. The survey response rate was $90.7 \%$ Data were analyzed using SPSS 16.0. We determined the correlations, means, and standard deviations for each variable.

Content/ Construct validity; Survey was piloted by a free sample of managers within the chain especially HR managers. Then the survey was piloted again by researchers and experts in HRM. This pilot process enabled the researchers to correct, add, discuss and rearrange questions. Then, the study used Face to face questioning techniques in particular to provide feedback to respondents immediately upon collecting the data. This, in turn, check the validity and relevance of data as it is collected. 


\section{Results and discussions}

\section{Part one: Questionnaire Results}

1- The first construct: the management perception about the importance of job description form (JDF).

Table (1) importance of job description form

\begin{tabular}{|l|l|l||}
\hline \multicolumn{1}{|c|}{ Factors/ variables } & Mean & \multicolumn{1}{|c||}{ SD } \\
\hline Opens everyone's mind to better ideas and positive interactions. & $\underline{\mathbf{4 . 6}}$ & 0.429 \\
\hline Provides calm and focused beginning to each task. & 4.0 & 0.76 \\
\hline $\begin{array}{l}\text { Provides a philosophy statement; a list of required skills; a list of other } \\
\text { job activities; and a list of responsibilities\& accountabilities. }\end{array}$ & 4.26 & 0.93 \\
\hline Provides information about how job performance will be evaluated. & 4.27 & 0.99 \\
\hline Leads to good understanding and good performance. & 4.0 & 0.61 \\
\hline Clears descriptions of tasks help flowing of communication. & 3.8 & 0.44 \\
\hline Eliminates misinterpretation & $\underline{\mathbf{3 . 6 7}}$ & 0.82 \\
\hline Delineates the expectations for each competency. & 4.26 & 0.76 \\
\hline Reflects the expectations, values, and priorities of a role. & 4.3 & 0.93 \\
\hline Clears organizational relationship & 4.1 & 0.633 \\
\hline Implies skills identification & 4.3 & 0.61 \\
\hline Develops explorative behavior & 4.63 \\
\hline Enhances labor relations & 4.3 & 0.43 \\
\hline Helps employees in deciding their career paths. & 4.83 \\
\hline \hline
\end{tabular}

Table (1) revealed high perception of managers about the importance of job description form within the workplace (the total mean is 4.1). They highly realize the profits of JDF. This means that this tool is not just a pieace of paper within the employee file. The majority of managers and assistant managers responses were (agree). The mode of that was 4 which indicates the selection (agree). The management realizes that JDF opens everyone's mind to better ideas and positive interactions. This refers to the importance of the fact that 
JDF should be specific and well formalized using verbs which should be easily measured. This result coincides with what stated by Manning et al. (2012) and Bart (2012) who indicated that JDs should be more determined rather than vague, written in behavioral terms, and use quantitative verbs to describe actions. This formalization enables the employee to enlarge his ideas and know exactly what should he do to perform the job. Management of Mercure chain also realizes that JDF is fruitful in determining the lines of responsibility and authority within the organization chart. This is a good result because tasks are varied and hospitality in its nature is highly intensive employment industry. When every employee knows specifically what are his responsibility and the extent of his authority this will push him to achieve targets and goals smoothly. Conflict will appear if the employee responsibility was vague or muddy. Authority should be clear, if not the end result can't be evaluated and problems won't be solved. This result agrees with that of Berkeley (2016) who stated that job description provides a solid foundation for all management actions. It also dictates success or, conversely in its absence, allows a climate of conflict, shoddy work practices, vague and subjective performance evaluations, and organizational disharmony. The above variables results support the first hypothesis.

\section{2- The second construct: the extent of using JDF as a planning tool:}

Table (2) JDF as a planning tool

\begin{tabular}{|c|c|c|}
\hline Factors/variables & Mean & SD \\
\hline $\begin{array}{l}\text { Management uses job description form to specify performance reviews to } \\
\text { every practice. }\end{array}$ & 3.49 & 0.711 \\
\hline Management uses job description form in determining job Competencies. & $\underline{2.29}$ & 0.50 \\
\hline $\begin{array}{l}\text { Management uses job description form in forecasting human resource } \\
\text { needs. }\end{array}$ & 3.74 & 0.42 \\
\hline Management uses job description form to plan job design and facilities. & 3.22 & 0.9 \\
\hline Management uses job description form to identify workplace design. & 3.23 & 0.71 \\
\hline $\begin{array}{l}\text { Management uses job description form to construct performance } \\
\text { evaluations. }\end{array}$ & 3.74 & 0.43 \\
\hline Management uses job description form to develop skills inventory pool. & 3.6 & 0.43 \\
\hline $\begin{array}{l}\text { Management uses job description form as a cost indicator in the } \\
\text { organization. }\end{array}$ & 3.74 & 0.33 \\
\hline $\begin{array}{l}\text { Management uses job description form in defining the quality standard of } \\
\text { work. }\end{array}$ & $\underline{4.00}$ & 1.3 \\
\hline Management uses job description form to establish a performance plan. & 3.49 & 0.42 \\
\hline Management uses job description form as key clue in benchmarking. & 2.98 & 0.9 \\
\hline
\end{tabular}




\begin{tabular}{|l|l|l|}
\hline \multicolumn{1}{|c|}{ Factors/ variables } & Mean & SD \\
\hline $\begin{array}{l}\text { Management uses job description form in employee discussions to } \\
\text { develop descriptions. }\end{array}$ & 3.23 & 0.83 \\
\hline $\begin{array}{l}\text { Management uses job description form as a guide in promotion and } \\
\text { transfer. }\end{array}$ & 3.50 & 0.50 \\
\hline Total mean & $\mathbf{2 . 9}$ & $\mathbf{0 . 8 1 8}$ \\
\hline
\end{tabular}

Planning is a vital function that there is no way to neglect. The absence of planning is actually the planning to failure. In the context of JDF as a planning tool, the study detects the basic functions of JDF related to planning. The results shown in table (2) showed that the management uses job description form in defining the quality standard of work. The mean of this variable was (4). This is the highest practice in using JDF in planning. This means that the management of the chain determines the quality standards according to the duties and specifications prescribed in JDF. This practice organizes skills of employment and put these skills as a baseline to the quality needed. If, for example, the quality standard of a specific course within the menu contains varied vegetable cuts, varied colors, varied garnishing, specific taste and specific sequences, the skills of the chef should be suitable to do the standard.

Standard responsibilities of jobs and specifications needed for each job are all the main determinants of quality at the workplace. Management of Mercure chain has best practices in using JDF as a planning tool as depicted in table (2). We can arrange these practices beginning with the best practice to the lower ones according to the Means of variables. Forecasting HR needs and constructing performance evaluations are the best practices. Of course these two results (mean=3.74) represent big issues in planning of human resources within hotel industry. Forecasting needs is important in cutting excessive costs and help preparing the annual budget. Performance evaluation is also vital in profits, controlling, training decisions and corrective actions needed if failures occurred. Management of the chain also uses JDF to develop skills inventory of Mercure human resources (mean=3.6). It is important to the hotel industry to simultaneously develop employees' skills to be an up-to-date super competitor with the world fierce competition. Skills equal payment scale, quality, training cost and profits. Specific issues should be paid more attention concerning the role of JDF in planning. The above results coincide with Rohr (2016) and Kondrasuk et al. (2001) who stated that any performance deficiencies, as identified during the performance evaluation or the hiring process, can be addressed to training because the performance evaluation and hiring process are based on the job descriptions. In addition, job descriptions can play a vital role in successive planning. Organizations utilizing information systems can carefully create an inventory and track employees' knowledge, skills, abilities and behaviors. Minimum competencies in the job description should consist of a list of skills, knowledge, and behaviors that are required for performing the job. Competencies should be paid more attention in the formation of JDFs within the chain. Management response to the variable of using the JDF in determining competencies is not satisfied. The mean of that factor was less than 2.5. 
3- The third construct: the extent of using JDF in the administration of HR in Mercure chain:

A. Using JDF in recruitment and selection of candidates;

Table (3) Using JDF in recruitment

\begin{tabular}{|l|l|l|}
\hline \multicolumn{1}{|c|}{ Factors/ variables } & Mean & \multicolumn{1}{|c|}{ SD } \\
\hline $\begin{array}{l}\text { Management uses JDF to match the quality of human resources to the } \\
\text { requirements of workstations }\end{array}$ & $\underline{\mathbf{3 . 7 6}}$ & 0.33 \\
\hline Management uses JDF to develop an optimized policy of recruitment. & 4.01 & 1.3 \\
\hline Management uses JDF for personnel selection & 4.01 & 0.42 \\
\hline Management uses JDF in job-related interview questions. & 4.00 & 0.9 \\
\hline Management uses JDF to support perfect judgment of candidates. & 4.26 & 0.7 \\
\hline Management uses JDF to write job advertisements. & $\underline{\mathbf{4 . 3 5}}$ & 0.43 \\
\hline Management uses JDF in evaluating job candidates. & 4.26 & 0.66 \\
\hline Total mean & $\mathbf{4 . 0 8}$ & $\mathbf{0 . 7 2 5}$ \\
\hline
\end{tabular}

Table (3) illustrates the extent of Using JDF in recruitment and selection of candidates. Management of Mercure chain emphasized a good degree of agreement concerning the majority of variables (the total mean is 4.08). This is a normal result because recruitment should depend mainly on JDF. The total mean of that construct was 4.08. The standard deviation is significantly low. This means that all responses were agree on the variable of the construct. The dispersion among values was narrow. The management uses JDF and depends on its elements to design advertisements of employment. JDF enables the management to formalize skills needed, tailor the needed candidates, use the suitable media and write the end advertisement. The management of Mercure claimed that they use JDF as an administration tool to evaluate the suitability of the candidate to the job and to take the decision of selecting specific candidates (4.26).

Here, the JDF plays an important role in standardizing the recruitment policy of the chain. This can decrease the complaints of unfair and biased practices during hiring employees, on the other side, can attract good qualities and match the right people with the right jobs. Also, the image of the chain will be enhanced at the marketplace. These results agree with Sîrbua \&Pinteaa (2014) and Massad (2005). They argued, typically, until the identification of detailed and accurate requirements for the holder of a work station, both in terms of tasks and required behavior, we cannot design a professional recruitment system. They also focused that JDs mainly used as a strategic HR tool (Job evaluation, recruitment of staff, personnel selection, training of staff (Lee et al., 2014). Furthermore, the human resources department might take advantage of these JDs in order to develop an optimized policy of recruitment (Bednarek-Michalska; 2002). Peregrin (2014) argued that employing and selecting the wrong worker can have bad effects on the organization's morale and stress levels. In addition, ineffective hires can cost an employer $\$ 25,000$ according to findings published by the National Business Research Institute, while the US Department of Labor estimated the cost of a bad hire to be $30 \%$ of the employee's annual salary. So, competency-based hiring not only improves recruitment efforts, but also enhances the retention of knowledgeable employees (Scott, 2011). 
In addition, the study analyzed the correlation between the extent of agreement on using JDF in planning and the use of JDF in recruitment and selection. The results of simple linear correlation derived from SPSS showed a positive correlation between these two variables. Pearson correlation was $0.86 \& R^{2}=0.74$. The line of correlation was positive. This means that managers responses increase and also the degree of agreement on recruitment and selection increase. This means that if they used JDF in planning issues they also used it as administrative tool in recruitment and selection. This correlation supports the validity of the second hypothesis.

\section{B. Using JDF in the administration of payroll;}

Table (4) Using JDF in payroll

\begin{tabular}{|l|l|l|}
\hline \multicolumn{1}{|c|}{ Factors/ variables } & Mean & \multicolumn{1}{|c|}{ SD } \\
\hline $\begin{array}{l}\text { Management uses JDF in preparation of the pay scale according to the } \\
\text { estimation of job contribution to the organization in terms of skills, } \\
\text { responsibilities. }\end{array}$ & 4.00 & 0.50 \\
\hline Management uses JDF in pricing jobs. & $\underline{\mathbf{4 . 3 3}}$ & 0.43 \\
\hline Management uses JDF to accurately assess compensation levels. & $\underline{\mathbf{2 . 1}}$ & 0.43 \\
\hline Management uses JDF to perform objective performance appraisals. & 3.76 & 0.43 \\
\hline Total mean & $\mathbf{3 . 5}$ & 0.512 \\
\hline
\end{tabular}

Duties, responsibilities, skills, competences and experiences all form the baseline of pricing and determining the structure of salaries and wages within any business. Payroll management constitutes a large sum of operation costs. So, it is extremely vital to depend on JDF data to well administer and manage these costs. Table (4) illustrates how Mercure management depends on using JDF data as an administrative HR tool in relation to payroll. This management uses JDF in pricing jobs (mean=4.33). They depend on JDF in preparing the pay scale according to the estimation of job contribution to the organization in terms of skills, responsibilities (mean=4). They also use JDF in performance appraisals (mean=3.76). But they did not depend on JDF in the assessment of compensations of employees. Here, it should be emphasized that it is important to clarify all entitled parties of compensation as JDF draws responsibilities and clears duties. The total mean of the construct was (3.5).

The above results coincide with those stated by George\& Zakkariya (2015) who stated that human resources represent one of the most important investments of the company so managers should match members to the goals, recognize the differences, use goals and ensure that they are attainable, individualize rewards and link them to performance. 


\section{Using JDF in the administration of training;}

Table (5) Using JDF in training

\begin{tabular}{|l|l|l||}
\hline \multicolumn{1}{|c|}{ Factors/ variables } & Mean & \multicolumn{1}{|c||}{ SD } \\
\hline $\begin{array}{l}\text { Management uses job description to determine the defects and errors of } \\
\text { employees in work. }\end{array}$ & 3.76 & 0.33 \\
\hline Management uses job description to plan training programs. & 3.76 & 1.3 \\
\hline Management uses job description to build a system of staff evaluation. & 3.76 & 0.42 \\
\hline Management uses job description in determining training facilities. & 3.00 & 0.9 \\
\hline Management uses job description in career development training. & 3.24 & 0.83 \\
\hline $\begin{array}{l}\text { Management uses job description to determine skill gaps in relation to the } \\
\text { position. }\end{array}$ & $\underline{\mathbf{3 . 1}}$ & 0.503 \\
\hline Management uses job description in identifying training needs. & $\underline{\mathbf{4 . 3 0}}$ & 0.43 \\
\hline Total mean & $\mathbf{3 . 5 6}$ & $\mathbf{0 . 4 4}$ \\
\hline
\end{tabular}

Training for organizations is vital to success and competition. Training comprises major cost in HRM functions. Training is also a double edge weapon as the management enhances performance and increases profits and the latter consider training to be beneficial to their CVs. Thus the hotel should plan for training so well. Here table (5) indicates the extent of using JDF in the administration of training in the context of Mercure chain. The total mean was (3.56). The management indicates that it identifies training needs using JDF data. Well, this means that it analyzes performance according to the actual employee tasks. it also analyzes the contents of each cluster of JDF responsibilities and duties to form the training needs. New employees also need training according to the tasks associated with their work. The training need may arise from the analysis of mistakes and faults of entitled employees, so the management should depend on assigned tasks and responsibilities written within the JDF. Mercure management assured this practice. The mean equals (3.74). Training gives three outcomes, namely skills, knowledge and attitudes. The four basic functions within the training process are assessing, planning, acting and evaluating. The management emphasized the role of JDF in planning for training but the role of JDF in assessing skills gap needs some attention. The mean $=3.1$.

The role of JDF is vital to all HRM functions. The new trends of quality and strategic planning focus on the strong relationships among all activities all over the entire organization. These results agree strongly with Pennell (2010) who declared that Effective JDs can enable the organization to set goals and objectives for annual reviews, identify areas for professional development and training and enhance employee engagement and retention of employees. Also, JDs can be beneficial to having challenging and meaningful work force, more loyal to their profession than to the organization, less accommodating of traditional structures and authority, more concern about work life balance.

The above results of dispersion measure (standard deviation was low). This means that respondents' values were close related to each other and the total mean is highly represent the views. In addition, the study analyzed the correlation between the extent of agreement on using JDF in planning and the use of JDF in the 
administration of training. The results showed a positive correlation. Pearson correlation was $0.63 \& \mathrm{R}^{2}=$ 0.40 . This means that managers' responses to planning increase and also does the degree of agreement on the use of JDF in training. This correlation supports the third hypothesis.

Part two: the content analysis of Kitchen's JDFs and its relationship with the training plan of Mercure chain in the year 2016.

Table (6) training/JDF matrix

\begin{tabular}{|c|c|c|c|c|c|}
\hline $\begin{array}{l}\text { Operational goals / Expected results (each } \\
\text { goal relates to one program) }\end{array}$ & $\begin{array}{l}\text { Target } \\
\text { group }\end{array}$ & $\begin{array}{l}\text { Operati } \\
\text { onal } \\
\text { duties }\end{array}$ & $\begin{array}{l}\text { Operati } \\
\text { onal } \\
\text { skills }\end{array}$ & $\begin{array}{l}\text { Manage } \\
\text { rial } \\
\text { skills }\end{array}$ & $\begin{array}{l}\text { General } \\
\text { skills }\end{array}$ \\
\hline $\begin{array}{l}\text { Prog. 1- To identify guest expectations \& } \\
\text { personalize welcome }\end{array}$ & All staff & $\sqrt{ }$ & $\sqrt{ }$ & & \\
\hline $\begin{array}{l}\text { Prog. 2- To increase team members } \\
\text { involvement in decision process }\end{array}$ & Supervisors & & & $\sqrt{ }$ & \\
\hline $\begin{array}{l}\text { Prog. 3- Present the staff in professional } \\
\text { manner to be a brand ambassador }\end{array}$ & All & & & & $\sqrt{ }$ \\
\hline $\begin{array}{l}\text { Prog. 4- Look into facts and methods of } \\
\text { problem solving }\end{array}$ & Supervisors & & $\sqrt{ }$ & & $\sqrt{ }$ \\
\hline $\begin{array}{l}\text { Prog. 5- Be aware of the secrets of hospitality } \\
\text { and behaviors }\end{array}$ & All & & & & $\sqrt{ }$ \\
\hline $\begin{array}{l}\text { Prog. 6- Learn about Roles and missions - } \\
\text { what has changed in my role and } \\
\text { responsibilities }\end{array}$ & All & $\sqrt{ }$ & $\sqrt{ }$ & & \\
\hline $\begin{array}{l}\text { Prog. 7- Enable team to work smoothly and } \\
\text { efficiently at all times }\end{array}$ & Supervisors & $\sqrt{ }$ & $\sqrt{ }$ & $\sqrt{ }$ & \\
\hline Prog. 8- Analyze the facts & Supervisors & & & $\sqrt{ }$ & $\sqrt{ }$ \\
\hline $\begin{array}{l}\text { Prog. 9- Manage time in terms of: Task, } \\
\text { communication and people }\end{array}$ & Supervisors & & & & $\sqrt{ }$ \\
\hline $\begin{array}{l}\text { Prog. 10- Evaluate, plan and distribution the } \\
\text { necessary resources and tasks }\end{array}$ & Supervisors & & & $\sqrt{ }$ & \\
\hline $\begin{array}{l}\text { Prog. 11- Assess skills in line with brands } \\
\text { specificities }\end{array}$ & Supervisors & & & & $\sqrt{ }$ \\
\hline Prog. 12- Evaluate and assess & Supervisors & & & $\sqrt{ }$ & \\
\hline Prog. 13- Effective Training management tool & Supervisors & & & $\sqrt{ }$ & $\sqrt{ }$ \\
\hline Prog. 14- Improve language skills & Supervisors & & & & $\sqrt{ }$ \\
\hline Prog. 15- Applying HACCP Procedures & All & $\sqrt{ }$ & $\sqrt{ }$ & & \\
\hline Prog. 16- 1st Aid Awareness & All & & $\sqrt{ }$ & & \\
\hline
\end{tabular}


Job description form as an approach to work quality: specifying problems and strategic planning tool: the case study of Mercure hotel chain

\begin{tabular}{|l|l|l|l|l|l|}
\hline $\begin{array}{l}\text { Operational goals / Expected results (each } \\
\text { goal relates to one program) }\end{array}$ & $\begin{array}{l}\text { Target } \\
\text { group }\end{array}$ & $\begin{array}{l}\text { Operati } \\
\text { onal } \\
\text { duties }\end{array}$ & $\begin{array}{l}\text { Operati } \\
\text { onal } \\
\text { skills }\end{array}$ & $\begin{array}{l}\text { Manage } \\
\text { rial } \\
\text { skills }\end{array}$ & $\begin{array}{l}\text { General } \\
\text { skills }\end{array}$ \\
\hline Prog. 17- Firefighting Awareness & All & & $\sqrt{ }$ & \\
\hline $\begin{array}{l}\text { Prog. 18- Understand the role of Food and } \\
\text { Beverages in the hotel }\end{array}$ & All & $\sqrt{ }$ & $\sqrt{ }$ & & $\sqrt{ }$ \\
\hline
\end{tabular}

Table (6) shows matrix analysis between the operational goals of the training programs and the data attained in the JDFs of the kitchen personnel in the context of Mercure chain. The study divided the contents of the JDFs into four sections (operational duties of entitled personnel, operational skills, managerial skills and general skills associated with the jobs. 50\% of training programs focused on the general skills commonly related to all supervisors within the kitchen. $45 \%$ of training courses in the year 2016 focused on operational skills of personnel within the kitchen. $33 \%$ of training programs dealt with managerial positions and gave managerial skills. $28 \%$ of the total training program 2016 tailored operational duties.

On the other side, $39 \%$ of programs was planned to tailor non managerial levels. $100 \%$ of courses tailored supervisory levels. The results within the matrix revealed specific issues; operational duties receive lower attention in the training plan and this may be a result of the frequency of that training programs so staff needs differed in the plan to highly concentrate on managerial skills and targeted supervisory levels. This point raises a concern that should be researched; why the training programs focused on supervisory levels more than operational levels although the gap in the skills may be great between the two levels? The second issue is the importance of skills in the training program plan within the context of Mercure chain. This reflects the sensitive role of hospitality industry as a service industry produces intangible product depend mainly on the skills of the humans. Another point raised here for research is the question; is the management depends on other sources of training needs assessment to build the program beside the JDF like customer viewpoint or competition in all?

\section{Conclusions}

Job description form JDF is a vital tool playing an important role in the functions of HRM. It is important to match the characteristics of personnel with the characteristics of the position. In order to work better, each employee must know and understand how to perform the job, and must also know that the form of description is not just a piece of paper within his/her file. It is vital tool to plan for your career path and the management should plan its activities and operations also using that vital form. JDF is not only an organizational activity, but is part of the professional development of each employee and the chain as whole. The activities of analysis, design and evaluation of job descriptions must be formed and revised with great care and professionalism, since they require significant time and effort. It is necessary for the manager to explain the role of JDF to the employees, and describe its impact on their work. It is also necessary to define positions in relation to staff features or peculiarities to achieve efficiency.

\section{Recommendations}

1. Attention should be paid to the use of JDF as an important clue in defining pay levels of employees.

2. Skill inventory index should be developed in HRM. Skills should be scaled for each task.

3. JDF should be revised and developed on regular basis using benchmarking and full employee involvement.

4. Additional research would be fruitful in the area of "the analysis of training programs to assess the effect of JDF on the training activity.

5. The management should create suitable skill set of employees by giving training, development of human capital and social prestige during formulating organizational policies.

6. The management should focus on modern job design activities (job related skills, employee motivation and well-being, organizational goal-oriented functions and responsibilities. 


\section{References}

Bart, C.; Evelien, K.; Van, V. M. and Hans, D. W. (2012),"Jobs and organizations: Explaining group level differences in job satisfaction in the banking sector ", Personnel Review, Vol. 41 Iss. 2, pp. 200 215.

Berkeley, J. (2016) "The Job Description Handbook: Effective Security Management", 2nd edition, Elsevier Inc., Canada.

Blickle, G.; Kramer, J.; Zettler, I.; Momm, T.; Summers, J. K.; Munyon, T. P. and Ferris, G. R. (2009),"Job demands as a moderator of the political skill-job performance relationship", Career Development International, Vol. 14 Iss. 4, pp. 333 - 350

Blickle, G.; Meurs, J.A.; Zettler, I.; Solga, J.; Noethen, D.; Kramer, J. and Ferris, G.R. (2008), "Personality, political skill, and job performance", Journal of Vocational Behavior, Vol. 72, pp. 377-87.

Carliner, S. (2012), "People management 1: job descriptions: communicating your general expectations", available at: http://commerceofcontent.wordpress.com/2012/11/14/peoplemanagement-1-jobdescriptions-communicating-your-general-expectations

Carliner, S.; Castonguay, C.; Sheepy, Emily.; Ribeiro, Ofelia; Sabri, Hiba.; Saylor, C. and Valle, A. (2015),"The job of a performance consultant: a qualitative content analysis of job descriptions", European Journal of Training and Development, Vol. 39 Iss. 6, pp. $458-483$

Chow, C. M. and Kleiner, B. H. (2002),"How to differentiate essential job duties from marginal job duties", Managerial Law, Vol. 44 Iss. 1/2, pp. 121-127

Gan, Marie and Kleiner, B. H. (2005),"How to Write Job Descriptions Effectively", Management Research News, Vol. 28 Iss 8, pp. 48 - 54.

George, Elizabeth and Zakkariya K.A. (2015),"Job related stress and job satisfaction: a comparative study among bank employees", Journal of Management Development, Vol. 34 Iss. 3, pp. 316-329

Heathfield, S. (2016), "Job description", Human Resources Management: HR FAQs and Basics and Strategic HR, available at: http://humanresources.about.com/od/jobdescriptions/g/job_description.htm

Herrick, S. (2009), "How job descriptions prepare you for interview questions", Cube Rules, available at: http://cuberules.com/2009/08/17/how-job-descriptions-prepare-you-for-interview-questions/

Hill, Susan, J. (1995),"Get that job - form filling and CV preparation", Librarian Career Development, Vol. 3 Iss. 3, pp. 24 - 27

Hsieh, Y. and Hsieh, A. (2003),"Does job standardization increase job burnout?", International Journal of Manpower, Vol. 24 Iss. 5, pp. 590-614

Kondrasuk, J.N.; Moore, H.L. and Wang, H. (2001), "Negligent hiring: the emerging contributor to workplace violence in the public sector", Public Personnel Management, Vol. 30 No. 2, pp. 185-195.

Lanier, C.R. (2009), "Analysis of the skills called for by technical communication employers in recruitment postings", Technical Communication, Vol. 56, No. 1, pp. 51-61.

Lee, Y.; Choo, Jina; cho, J.; Kim, S.; Lee, H. and Yoon, S. (2014) "Development of a Standardized Job Description for Healthcare Managers of Metabolic Syndrome Management Programs in Korean Community Health Centers, Asian Nursing Research journal, vol. , no. . Homepage: www.asiannursingresearch.com

Levin, R. P. (2005) " perspectives a better practice, how to build a better team", journal of American dental association, vol. 1, issue 3. Website: http://jada.ada.org

Linz, Susan J. (2003),"Job satisfaction among Russian workers", International Journal of Manpower, Vol. 24 Iss. 6, pp. 626-652

Manning, M. L.; Borton, D. L. and Rumovitz, D. M. (2012) "Infection preventionists' job descriptions: Do they reflect expanded roles and responsibilities?", American Journal of Infection Control, Vol. 8, no1.journal homepage: www.ajicjournal .org 
Marr, B. (2013), "The top 5 management tools in the world", LinkedIn, available at: www.linkedin.com/pulse/20130729060735-64875646-shhh-the-top-5-management-tools-in-the-world

Massad, M. (2005), "Importance of a job description", Entrepreneur, available at: www.entrepreneur.com/article/78506

Michalska, B. (2002),"Creating a job description for an electronic resources librarian", Library Management, Vol. 23 Iss. 8/9, pp. 378-383.

Mondy, R. and Martocchio, J. (2014), Human Resource Management, Pearson, Boston, MA, pp. 91-94.

Pennell, Kathy (2010),"The role of flexible job descriptions in succession management", Library Management, Vol. 31 Iss. 4/5, pp. 279-290.

Peregrin, T. (2014) "Competency-Based Hiring: The Key to Recruiting and Retaining Successful Employees", journal of the academy of nutrition and dietetics, vol. 12, no. 3, http://dx.doi.org/ $\underline{10.1016 / j . j a n d .2014 .07 .016}$,

Pradhanc, S. (2014) " Impacts of Job Analysis on Organizational Performance: An Inquiry on Indian Public Sector Enterprises", Symbiosis Institute of Management Studies Annual Research Conference (SIMSARC13), journal of Economics and Finance, vol. 11, no. 3, pp. 166-181. Available online at www.sciencedirect.com

Rohr, S. L. (2016),"Harnessing the power of the job description", Human Resource Management International Digest, Vol. 24 Iss. 6, pp. 8-11

Schmitt, N.; Cortina, J.M.; Ingerick, M.J. and Wiechmann, D. (2003), "Personnel selection and employee performance", in Borman, W.C., Ilgen, D.R. and Klimoski, R.J. (Eds), Handbook of Psychology, Vol. 12: Industrial and Organizational Psychology, Wiley, Hoboken, NJ, pp. 77-105.

Scott, N. (2011), "How to make job descriptions work with performance evaluations", Biz Articles Online, available at: www.nancyscott.com/page50/page43/page43.html

Sîrbua, Janetta and Pinteaa, Florin R. (2014) "Analysis and evaluation of jobs-important elements in work organization", journal of Social and Behavioral Sciences, vol. 1, no.24, pp. 59-68. Available online at www.sciencedirect.com

Stetz, T. A.; Button, S. B. and Scott, D. W. (2011) "Creating occupational groups using visual job classification", Management Research Review, Vol. 34 Iss. 3, pp. 294-310.

الملخص باللغة الغربية

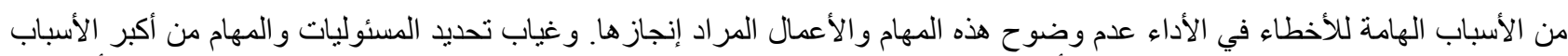

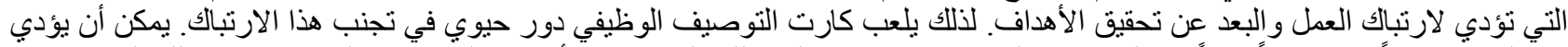

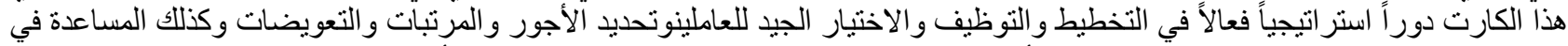

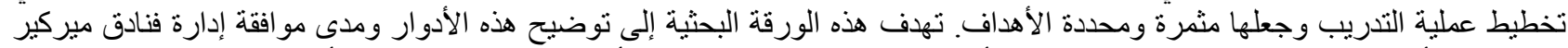

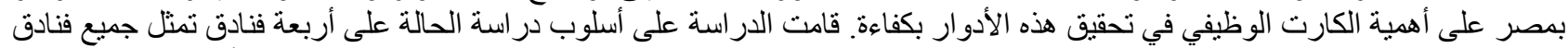

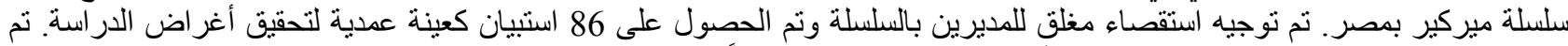

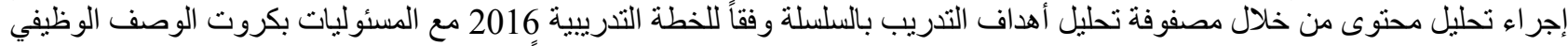

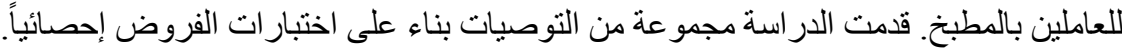
الكلمات الدالة: فنادق ميركير، إدارة المو ارد البشرية، التخطيط، التدريب 